\title{
Adding the ocean to the study of seabirds: a brief history of at-sea seabird research
}

\author{
David G. Ainley ${ }^{1}$, Christine A. Ribic ${ }^{2}$, Eric J. Woehler ${ }^{3}$ \\ ${ }^{1}$ H.T. Harvey \& Associates, 983 University Avenue, Los Gatos, California 95032, USA \\ ${ }^{2}$ US Geological Survey Wisconsin Cooperative Wildlife Research Unit, Department of Forest and Wildlife Ecology, \\ University of Wisconsin, Madison, Wisconsin 53706, USA \\ ${ }^{3}$ School of Zoology, University of Tasmania, Hobart, Tasmania 7005, Australia
}

\begin{abstract}
We review the history of how research directed towards marine ornithology has led to an appreciation of seabirds as highly specialized marine organisms. Beginning with R. C. Murphy (Pacific), V. C. Wynne-Edwards (Atlantic), and associates in the early 1900s, the research approach grew from an emphasis on seabird single-species ecology to an appreciation of interacting species assemblages and finally to seabirds being considered as important components of marine food webs. After a slow, drawn-out beginning, the initial main impetus for developing the field was a need to map seabird abundance and distribution tied to understanding impacts of continental shelf resource exploitation. Coalescing during the 1970s to 1980s to facilitate this line of research were 6 factors: (1) ability to identify birds at sea; (2) standardization of techniques to quantify abundance; (3) resources and techniques for mapping; (4) appreciation of how scale affects seabird relationships to hydrographic features and patchy prey; (5) development of computing power and appropriate statistics; and (6) seabird biologists becoming embedded in, as well as organizing, multidisciplinary marine research projects. Future advances in understanding the role of seabirds in marine food webs will be made by seabird biologists participating in multidisciplinary projects using grid-like surveys relative to oceanographic features in combination with instrumentation that reveals the finer details of seabird foraging behaviors.
\end{abstract}

KEY WORDS: At-sea surveys $\cdot$ Food-web structure $\cdot$ Foraging ecology $\cdot$ Seabird $\cdot$ Seabird habitat

\section{THE FOUNDATIONS}

Our appreciation of the marine ecology of seabirds, as opposed to their nesting ecology and behavior, began with scientists such as Jespersen and WynneEdwards in the Atlantic and Murphy in the Pacific. Working in the early part of the 20th century, all identified patterns in seabird distributions at sea. Wynne-Edwards (1935) proposed classifying seabirds into coastal, off-shore, and pelagic groups based on his observations in the North Atlantic. Jespersen (1924) collected information on plankton and seabirds on research cruises in the Atlantic; he noted a relationship of birds with distance to land but also postulated that some of the variation in seabird distribution he observed was related to variation in food resources. Murphy, working in the Pacific basin, went to coastal South America and in addition participated in several cruises to the adjacent Southern Ocean aboard whaling vessels; he was seeking to provide context to the multitude of specimens residing in major museums, particularly the American Museum of Natural History (AMNH) that employed him and still has one of the largest collections of seabird specimens in the world. Also available to him were the field notes and specimens amassed by Beck who, after being commissioned by the California Academy of Sciences and AMNH, ventured into the 
waters off California, around the Galapagos, and elsewhere in South (and North) America, by hitching rides on fishing vessels or rowing his dory well off the coast (see, for instance, Beck 1910). Murphy's summary of the 1000s of his, Beck's, and others' specimens and their marine context can be found in the 2volume treatise, 'The oceanic birds of South America' (Murphy 1936). In these 2 volumes, discussing the waters and their avifauna surrounding South America (including the Atlantic, Pacific, and Caribbean basins, as well as the Southern Ocean), Murphy introduced seabird aficionados to oceans that are partitioned by fronts into water masses, each with a characteristic seabird species assemblage and overall seabird density. This treatise by Murphy constituted the first synthesis of seabird ecology, having 31 pages of references, citing works dealing with all oceans (including work in the North Atlantic by Jespersen 1929 and Wynne-Edwards 1935). Pocklington (1965) found application of Murphy's findings to the delineation of species assemblages by water mass in the Indian Ocean, as since have others elsewhere in the world ocean (e.g. Bourne \& Warham 1966 in understanding occurrence patterns of Macronectes). Insights into Murphy's at-sea experience can be found in 'A log-book for grace: whaling ship Daisy, 1912-13', written well after his ocean traveling was completed (Murphy 1965).

Almost 4 decades later, Ashmole (1971) summarized what was known about seabirds near to island shores, in a book chapter entitled 'Seabirds and the marine environment,' based on his work in the 1960s. Ashmole's classification of seabird foraging methods is still in use today. Otherwise, studies of seabird marine ecology were given little attention until the 1970s when the designation of Exclusive Economic Zones (EEZs) by coastal countries and a push to develop petroleum resources became constrained by legislation such as the US National Environmental Policy Act of 1970. Due to that legislation, environmental impact assessments for activity on federal lands (in this case, the continental shelf) were required. At that point, surveys of the coastal ocean were needed to describe seabird abundance and distribution, and the 'golden age' of at-sea studies of seabirds began (Appendix 1). Though not propelled by legislation, efforts in other countries also led to seabird assessments and atlases elsewhere at this time (M. L. Tasker pers. comm.; Appendix 1).

Not only with these ship and airplane surveys did we begin to learn about seabirds at sea, but in the process marine ornithology added community eco$\operatorname{logy}$, i.e. the description of recurring species as- semblages and species associations, to its otherwise largely autecological emphasis. Grid-like and transect-driven survey efforts continued for a few decades, branching eventually into a few studies of actual seabird interactions with prey and ocean (not just atlases of horizontal distribution). Then in the late 1990s and 2000s, with the maturation of technology such as satellite, global locating system (GLS), and global positioning system (GPS) tracking and miniaturization of devices enabling the recording of dive behavior, in conjunction with remote sensing of surface features, none of which requires going to sea, increasing numbers of seabird ecologists began a return to single-species studies. Seabird movements were now being plotted against remotely-sensed ocean properties, rather than being observed in the marine environment.

During the 'golden age' of at-sea studies, we learned a great deal about the place of seabirds in their true element: the ocean where they spend $90 \%$ of their existence and for the exploitation of marine resources for which most of their morphology has evolved. Herein, we review this history in some detail, in part to complement the recent paper by Tremblay et al. (2009). Those authors sampled the seabird literature and described various broad trends in marine bird research over the past several decades by using an electronic key-word search that included positional data and at least 1 environmental variable (e.g. sea surface temperature, SST).

\section{FIRST ANALYSIS OF SEABIRDS AT-SEA STUDIES}

The main findings of Tremblay et al. (2009), analyzing trends based on frequency of papers discussing seabirds and spatial habitat features, including both indirect (instrument deployment from land) and direct (at-sea observation) efforts to understand seabird marine ecology, can be summarized as follows:

(1) Clumping studies by 5 yr bins beginning in 1970 and ending in 2005, it is evident that at-sea effort began slowly but in the most recent decades has accelerated. As a subjective, qualitative check, the frequency of our own papers involving direct at-sea work loosely paralleled the upward trend that Tremblay et al. (2009) described, although the increase was not as steep (Fig. 1).

(2) Marine research efforts were entirely shipbased up until the early 1970 s, then added aerial surveys through 1990s. Thereafter, land-based instrument attachment became the preferred means to learn about seabird at-sea movements. 


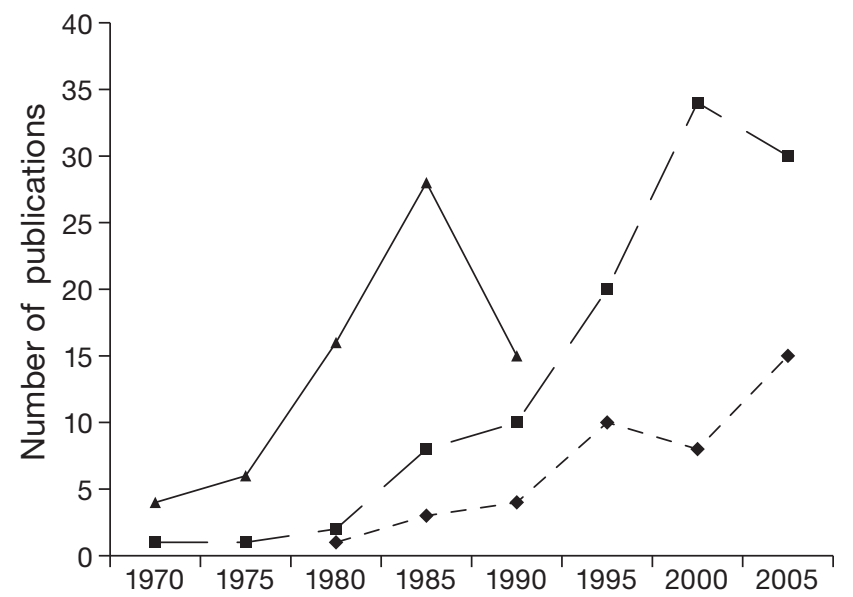

Fig. 1. Growth in the prevalence of at-sea studies judged by number of publications by $5 \mathrm{yr}$ bin: $(--)$ Tremblay et al. (2009); (-- ) authors' publications based on direct, at-sea work (those not included in Tremblay); (-) Scientific Committee for Antarctic Research (SCAR) list compiled in 1996 (papers not in Tremblay and mostly from non-westernEuropean, non-North American journals). Tremblay et al. (2009) detailed 106 direct (shown) and 112 indirect marine studies in the period 1970 to 2005

(3) Real time, in situ measurements of seabird habitat comprise at least $60 \%$ of the effort in each $5 \mathrm{yr}$ bin, with indirect measures (remote sensing) appearing in the mid-1980s and contributing a third by 2000.

(4) The habitat feature of choice is SST (25\% of studies).

(5) To summarize and analyze results, statistical and spatial modeling of various types appeared in the 1980s, and is now the preferred tool used to understand seabird presence with respect to ocean features.

We note that 1 especially important topic not treated by Tremblay et al. (2009) is how the quantity, quality, and dispersion of prey affects seabird occurrence. This topic, though it treats seabirds as wholly marine organisms (e.g. Brown 1980), is rarely investigated in most seabird 'marine' studies. Most of the latter operate under the assumption that seabirds are generalist predators and that physics and physical parameters explain enough about where the birds find food. This means that very few of the many papers by Hunt, Piatt, Spear, Veit, and their colleagues, investigating foraging behavior and diet from an at-sea perspective, and none of the papers by Nevitt, investigating multi-sensory foraging strategies including the role of olfaction, were included by Tremblay et al. (2009). It would take a book to summarize this literature, even that of Hunt alone; indeed, one could start with Stabeno et al. (2005), Ladd et al. (2005), Jahncke et al. (2005), Vlietstra et al. (2005), Hunt \& Stabeno
(2005), work backward, and spend several weeks reading about seabirds' roles in polar food webs, especially that of the Bering Sea. For now, instructive summaries of seabird foraging ecology were provided by Ballance et al. (2001) and, especially, Shealer (2002).

\section{FACTORS THAT SHED LIGHT ON THE RELATIONSHIP BETWEEN OCEANOGRAPHY AND SEABIRDS}

To understand how we have learned about why seabirds occur where they do and what they are doing while there, one has to keep in mind the progression or evolution of research foci that began with studies investigating single species, or 'autecology,' to 'community ecology' (synecology), and finally to 'ecosystem ecology.' During the 1960s, before the period studied by Tremblay et al. (2009), there was ample effort toward logging individual seabird species' occurrence on the ocean in terms of presenceabsence and relative abundance. Many of these data gathered were from 'ships of opportunity' as is readily apparent in Tuck's (1980) book, 'A guide to seabirds on the ocean routes.' During that early period, the US National Museum of Natural History (USNMNH), funded by the US Army which was interested in birds as disease vectors, undertook an intensive investigation of seabird colonies throughout the South Pacific. The effort was called the Pacific Ocean Biological Survey Program (POBSP), headed by P. Humphries and J. Church, and it included the logging of birds seen on passages among the islands and not-to-interfere participation in fisheries and oceanographic research cruises. This resulted in several publications, the most notable being King's (1974) work, 'Pelagic studies of seabirds in the central and eastern Pacific Ocean,' composed of several chapters, some of them atlas-like, treating different species or species groups. Second to Murphy's work, this was a pioneering study. Earlier work by King (1970) was among the first in which seabird biologists participated in oceanographic research cruises.

The efforts of the 1960s were mainly descriptive. Much of the work involved biologists from non-western European or North American countries. In fact, the later peak and falloff among these studies exhibited in Fig. 1 was to a large extent due to the disintegration of the Soviet Republic; basic natural history research took a major hit as the USSR collapsed. As it was, we did not begin to understand why certain species occurred where they did until work in the 1970s 
looked at seabird distributions at sea in relation to weather patterns (Manikowski 1971, 1975) and water masses (Brown et al. 1975, Pocklington 1979). In fact, the work by Brown et al. (1975) and Pocklington (1979) quantified the ideas of Murphy. Pocklington (1979) may have been among the first seabird papers to ever appear in a mainstream marine biology journal, now the norm for at-sea studies. From this period on, at least 6 coalescing paths of investigation have contributed to the evolution of seabird studies as we know them today. These 6 paths are discussed below.

\section{(1) What bird is that?}

In the 1960s and 1970s, crossing the oceans, one had to carry several kilograms of books, including Murphy (1936), as 'field guides;' or at least one of us had to (D.G.A.; see Gill 1967 for a similar opinion). The best guides available were the 'Preliminary field guides' by King (1967) as well as Watson (1965) and Watson et al. (1963) of USNMNH (based mostly on specimens) written to assist the POBSP biologists, and the Peterson Field Guide series, which were useful only in coastal waters. Alexander's (1955; a much less useable version appearing in 1928) 'Birds of the ocean' was also important to include in one's at-sea library. It was not until the appearance of Harper \& Kinsky's (1978) 'Southern albatrosses and petrels: an identification guide,' that we had the first seabird guide written by people who had actually spent a good deal of time at sea, and thus knew of the difficult viewing conditions typically experienced, in this case in waters around New Zealand and elsewhere in the Southern Ocean. Identifying birds at sea became possible without needing a library at sea! Their effort, as well as that of the qualitative data on seabird occurrence of the 1950 s to 1970 s, finally culminated in the 'bible' of seabird identification at sea, Harrison's (1983) 'Seabirds: an identification guide.' However, seabird identification is not static. The era of genetic analyses since the 1990s has led to the splitting of many 'species,' to which very able observers have been playing catch-up in order to identify field-visible identification characteristics (e.g. Robb et al. 2008, Howell 2009, Howell et al. 2010). This revolution has led to discovering new ranges for species, sometimes bigger and unexpected (e.g. Bailey et al. 1989, Pyle et al. 1993, Brinkley et al. 2000). A revised version of Harrison (1983) that reflects current taxonomies is now critically needed. The recent volume by Howell (2012) is now the standard to emulate.

\section{(2) Techniques for collecting quantitative data}

Until the paper by Tasker et al. (1984), with some exceptions, seabird data were largely qualitative presence-absence with large birds, e.g. albatrosses, over-emphasized because they could be seen farther away than small birds, e.g. storm-petrels. After reviewing the previously used methods, Tasker et al. (1984) proposed a standardized technique of using well defined strips, i.e. $300 \mathrm{~m}$ wide, with search effort broken temporally into fixed time segments, i.e. 'snap shots.' The Southern Ocean BIOMASS effort sponsored by the Scientific Committee for Antarctic Research (SCAR) collected data in 10 min bins, 1 in each hour of ship transit, with reports coming from different sectors of the Southern Ocean (e.g. Abrams 1985, Ryan \& Cooper 1989, Bretagnolle \& Thomas 1990). These data were compiled into species maps, which when compiled became 'atlases' (see next section). It was not until the continental shelf oil development studies that continuous transects became more common, due to the use of aerial surveys (e.g. Briggs et al. 1987, Schneider et al. 1987), but also used in ship-based ecological surveys as well, e.g. of the Ross Sea (Ross Ice Shelf Project, RISP; Ainley et al. 1984) and of the eastern tropical Pacific (EPOCS; Spear et al. 1995, Ribic et al. 1997).

It was recognized early on (e.g. Gould et al. 1982) that the issue of bird 'flux' needed to be statistically controlled because more birds are counted that are flying opposite to ship travel than those flying with the ship, and fast-flying species are over-counted relative to slow-flying ones or birds sitting on the water. The problem was identified by Tasker et al. (1984), who proposed using the 'snapshot' approach to avoid this bias (also see Gould \& Forsell 1989). A further solution to correct for flux, based on bird and ship speed and direction, was proposed by Gaston \& Smith (1984), but correction for flux became more widely used as a result of Spear et al. (1992; also see Spear \& Ainley 1997). While there is still debate about the conditions under which one technique might be better than the other (e.g. continuous counts when seabirds are in low densities and snap-shot methods when there are high densities; also see van Franeker 1994), both of these techniques led to higher precision of surveys. In particular, the use of at-sea data was used to estimate population size of burrowing species for which population estimation is difficult to accomplish (Clarke et al. 2003); this latter work to date is the only one that tested the agreement between at-sea census results compared to island-based censuses. Precision was also achieved 
by the development of line transect methodology (Burnham et al. 1980), although the collection of distance and angle data precludes the use of this technique for species other than single, special-status species, such as marbled murrelets Brachyramphus marmoratus (Ralph et al. 1995; also see Tasker et al. 1984) or species standing on ice such as penguins (Southwell \& Low 2009).

\section{(3) Mapping at-sea seabird distributions}

We touched on this briefly above in reference to the 'golden age' of at-sea studies. Huge resources were put into mapping seabird and other biota in areas where offshore oil development had been proposed. The studies were done before lease sales were held. Examples are the Outer Continental Shelf Assessment Project (OCSEAP) and the Programme Intégré pour le Recherche des Oiseaux Pélagiques (PIROP). Shelf waters could not be leased by governments to oil companies until environmental impact studies (EIS) were completed, and those could not be completed until the potentially affected biota were mapped. In fact, many seabird biologists were employed to do this, which in itself was a first, as before EIS requirements only university professors were paid, with their students, to conduct seabird studies as part of basic rather than applied research. The EIS effort relative to offshore oil development also led, in large part, to the founding of the Pacific Seabird Group.

The mapping needed in EISs led to the production of seabird atlases, which now cover much of North American and European coastal waters (Appendix 1). The first were those by Brown et al. (1975, with updates in 1977 and 1986), but if one now searches the web using the words 'seabird atlas' one will receive, currently, 229000 entries (which would also likely include seabird colony catalogs). These atlases are essentially grids in which relative or absolute abundance of each species is shown relative to coastal and bathymetric features. The information for most of these atlases is contained in data bases that are readily available, and are now used, for instance, in assessments of oil spill impacts and are often updated (Appendix 1). A good example is Briggs et al. (1987), which has since been repeatedly updated for a portion of the California coast where oil exploration is still active (Mason et al. 2007). Consistent with the need for rapid assessment of damage during oil spills, surveys like those reported in the latter 2 publications are now mostly done by aircraft.
Those data, too, were used subsequently by NOAA (2008) for purposes of marine sanctuary management plans. Globally, there is presently an increasing effort to incorporate the distribution of seabirds at-sea into planning and the identification of candidate areas for consideration of Marine Protected Areas (MPAs) in coastal areas (e.g. Sala et al. 2002), and at regional (Lombard et al. 2007) and ocean basin (Harris et al. 2007, Trebilco et al. 2008) scales. In Europe, a coalition of researchers formed European Seabirds at Sea (ESAS), which combined the results of most European at-sea studies into 1 data base. This is accomplished in North American waters by contractors to NOAA (e.g. Compilation of Data At-Sea, CDAS). These data banks have been used in efforts to invoke ecosystem-based management in fisheries, in both Europe (International Council for the Exploration of the Sea, ICES, Working Group on Seabird Ecology) and less successfully in the Pacific (PICES); the majority of the ICES data, however, are colony based, which is not covered in the present review.

Perhaps most critically, it is important to note that these atlases provide valuable baseline historical data for current and future surveys, should they be repeated, to assess the predicted effects and unexpected consequences of climate change or other drivers on marine ecosystems.

\section{(4) Attention to scale}

The scale at which we perceive seabirds in the context of ocean features had been recognized from the beginning (e.g. Murphy 1936), but once hypothesis testing was introduced in seabird research (see next section) it had to be addressed specifically. In one of the first review papers, Hunt \& Schneider (1987), following Schneider \& Duffy (1985), synthesized the ideas of scale in relation to the biology and physics of marine phenomena (Haury et al. 1978) as it applied to seabirds at-sea. In part recognizing the importance of scale came about in attempts to match bird patches with prey patches determined by acoustics (e.g. Schneider \& Piatt 1986). Various large data bases have since been useful in further applications of scale to seabird occurrence relative to ocean features (e.g. Ford et al. 2004, Huettmann \& Diamond 2006). This path has not progressed much beyond the ideas discussed by Hunt \& Schneider (1987). Advances in statistical techniques (discussed in the next section) have the potential for informing a deeper understanding of the role of scale in seabird-prey ecology (e.g. Logerwell et al. 1998). 


\section{(5) Statistics and controlling factors}

Initial attempts to understand factors affecting seabird distributions related bird species occurrence to simple ocean features (SST and sea surface salinity [SSS]), not necessarily collected simultaneously (Brown et al. 1975, Pocklington 1979, Abrams \& Griffiths 1981). There was also the limitation of access to computers and the software to analyze the seabird data. In fact, some data compilations, such as those led by W. Bourne in the Northeast Atlantic in the 1970s, were never properly written up because of being overwhelmed by the 'too much data' problem (M. L. Tasker pers. comm.). The first computer taken to sea by D.G.A. and G. Divoky was fitted into a steamer trunk, having been made from a kit in L. Karl's garage; it accompanied those biologists on a cruise from Long Beach, California, USA, to McMurdo Station, Antarctica, in 1977, making the process of data entry much easier than all the coding of data sheets that went on previously. It did not take long for this advance to be overtaken by the continuing computer revolution: direct data entry from the ship's bridge (Updegraff \& Hunt 1985).

Then with the issue of scale being incorporated into analyses, and the development of ever more powerful (and smaller) computers, seabird researchers played a game of catch-up to the rapid evolution then underway in statistics, somewhat as follows, in a movement that increasingly emphasized community ecology (multi-species assemblages): (1) contingency tables were used (Haney 1986a), along with multivariate statistics (Ribic \& Ainley 1988/89), to look at how species assemblages use different water masses; (2) seabird densities relative to ocean properties began to be modeled, initially as a Gaussian function of SST (Abrams \& Lutjeharms 1986); (3) correspondence analysis was used to model non-linear relationships between seabirds and physical oceanographic variables (Abrams \& Underhill 1986); (4) cluster analysis and multivariate statistics were used to delineate latitudinal ocean features and multispecies assemblages (Ribic \& Ainley 1988/89). By the 1990s, continuing into the 2000s, spatial statistics came into use, including the use of spatial point patterns (O'Driscoll 1998) and spatial error structures in linear models (Ainley et al. 1998). Advances in the linear model (e.g. generalized linear models) allowed the use of other error structures (beyond Gaussian) and incorporated nonlinear relationships beyond polynomial forms (e.g. generalized additive models; Woehler et al. 2001). Advances in model selection (e.g. Akaike's information criterion, Bayesian Infor- mation Criterion) allowed researchers to test competing non-nested models and move beyond reliance on p-values (Chapman et al. 2004). Further development of computer power allowed even more sophisticated analyses to look for and understand occurrence of individuals and species assemblages relative mainly to physical features and to explore patterns in the data rather than relying on specified statistical models (e.g. classification and regression trees, Ribic \& Ainley 1997). Computer-based techniques have developed whereby habitat models can be constructed to (reliably) fill in gaps of spatial coverage on the basis of species' correlations with specific habitat features (e.g. Raymond \& Woehler 2003, Nur et al. 2011). For more examples of modern statistical techniques used in at-sea marine ornithology, see Tremblay et al. (2009).

\section{(6) Seabirds as part of the ecosystem}

Seabirds finally attained the status of bona fide marine organisms (i.e. the respect of other marine biologists) when seabird biologists began to embed themselves into at-sea biological oceanography and fisheries projects. The first was Processes of the Bering Shelf (PROBES) in the 1980s, being also among the first investigations of seabirds and fronts. With such studies, it became apparent that the relationships of seabird at-sea distribution to seabird prey (e.g. type, abundance, patchiness), and not just physical features, were important (Hunt \& Schneider 1981, Kinder et al. 1983, Hunt et al. 1990, Hunt \& Harrison 1990). Another, somewhat coincident investigation was RINGS, a study of Gulf Stream warmand cold-core rings, on which seabird researchers piggy-backed (Haney 1986a,b,c, 1987). These sorts of ecosystem efforts launched a search for seabirdprey associations, especially using acoustics to quantify the patchiness of prey usually with single seabird species in mind (e.g. Woodby 1984, Obst 1985, Piatt 1990, Veit et al. 1993, Mehlum et al. 1999, Fauchald et al. 2000). The study by Veit et al. (1993) is interesting when compared to that of Hunt et al. (1992), who used the same prey data base but different correlates, and taken together presented somewhat confounding patterns of seabird occurrence near South Georgia colonies. At the least, these studies showed further, independent of scale, the complexity in dealing with seabirds and their supposed prey patches. The subject in fact has been taken even to being resolved by fractal analysis (Russell \& Hunt 1992)! 
An appreciation of seabirds as marine organisms, and their role in food webs, was finally achieved in the late 1980s when seabird biologists became active participants in multi-researcher investigations, playing a role in project and cruise design. The first was Antarctic Marine Ecosystem Research in the Ice Edge Zone (AMERIEZ), a multi-ship, multi-season, multi-investigator study of physics and biology of the Antarctic marginal ice zone. A seabird biologist was actually co-chair of the steering committee and chief scientist of one of the vessels, thus helping to direct the entire sampling effort. Much about the marine biology of seabirds was learned (e.g. Fraser \& Ainley 1986, Ainley et al. 1986, 1992, Rau et al. 1992).

Coincident with that effort, though not one that is full-on multidisciplinary, Hunt and associates put together cruises in 1983 to 1986 that included zooplankton sampling using both acoustics and nets (Hunt \& Harrison 1990, Hunt et al. 1990), and expanded the effort to include a physical oceanographer for cruises in 1991 and 1992 in the western Aleutians (see Hunt et al. 1998). This paper was slow to complete, but was successful in closely integrating birds, plankton, and physics at the same space and time scales (a precursor to Global Ocean Ecosystems Dynamics, GLOBEC, see below). This was followed by a National Marine Fisheries Service (NMFS) eastern tropical Pacific tuna-porpoise assessment program, again with seabird or top predator biologists playing a central role in planning, this time investigating the ecology of tuna and their associates (birds, mammals). The project related species densities to in situ and satellite-generated ocean properties, like chlorophyll (Ballance et al. 1997, 2006). Another multi-investigator example is Baseline Research on Oceanography, Krill, and the Environment (BROKE), which conducted an extended cruise to determine how ocean circulation off East Antarctica affected the occurrence of top predators and their prey (Nicol et al. 2000).

Finally, with the passing of the 20th and arrival of the 21st century, the international program GLOBEC was formed to investigate some problematic fishery questions, specifically what happened to Atlantic cod Gadus morhua (study area is George's Bank); what happened to Pacific salmon Oncorhynchus spp. (study area is the northern California Current); and what happened to Antarctic krill Euphausia superba (study area is the western Antarctic Peninsula; www. globec.org; Hofmann et al. 2004, Batchelder et al. 2005)? GLOBEC sought to understand the dynamics of middle-trophic level species (coincidentally, seabird prey), in conjunction with temporal and spatial ocean variability, as key to learning why major fish stocks were changing. Seabirds (and marine mammals) were seen by this program as being fundamental to answering those questions, given their competition with or predation of these fish. Therefore, marine ornithologists were members of steering committees. By this time, the computer revolution that had aided the analysis of seabird (and other large) data sets, as well as adding remote sensing capabilities, had also led to the ability to collect biological and physical ocean data in real time, which could help to explain the occurrences of seabirds and their prey in a way never before imagined. This was accomplished through towed arrays (SeaSoar, Biomapper) having acoustics and other electronic sensors to quantify in a continuous fashion such variables as chlorophyll and its depth maximum, SST, SSS, thermocline and pycnocline depth, and dynamic height, as well as biomasses of fish and invertebrates among several size classes. Given that all data were continuously collected, any scale of variation could be investigated at least through the meso-scale. The current effort involves the construction of 'end-toend' food-web models, in which one back-calculates trophic connections starting at the top of the food web. A number of publications to date have resulted, showing that, indeed, seabirds and large fish, both being mesopredators, interact in important ways that help to structure the food webs of which they are a part (Chapman et al. 2004, Ainley et al. 2005, 2009, Ribic et al. 2008, Ainley \& Hyrenbach 2010).

\section{THE FUTURE}

As noted by Tremblay et al. (2009), studies of seabirds' interactions with the oceans have recently been evolving from Eulerian (grid-like) to Lagrangian (particle-like) as researchers in increasing numbers turn to the wonders of electronic miniaturization to investigate seabird movements both over and within the sea in the context of variables easily quantified spatially by remote sensing (e.g. SST, chlorophyll, sea level height, sea ice cover). The grid-like and ecosystem studies, such as AMERIEZ and GLOBEC, provided validation for the collection of these variables via remote sensing to explain seabird occurrence. Actually, though, what has been happening is that marine ornithology is reverting to its initial roots of investigating the autecology of individual species, but with much more sophistication and detail and over every possible scale. The much steeper ascent in the numbers of marine-related papers in the broader 
community compared to our own effort of direct atsea effort (see Tremblay et al. 2009) bespeaks the rise in the use of high-technology in the seabird field, in a sense beginning to overwhelm at-sea research.

Most remotely-sensed data are at relatively coarse spatial and temporal scales, which may prevent the sensing technology from detecting features of interest to foraging birds. The latter are likely to be operating at much finer scales. However, this coarseness can work for at-sea studies by reducing the complexity of the habitat for researchers, and may be particularly useful for our understanding of species that cross ocean basins where we cannot integrate the environmental heterogeneity at such large spatial and temporal scales. It is the balance between environmental heterogeneity and 'homogeneity' that is critical for analyses (e.g. Shaffer et al. 2006, Raymond et al. 2010). Fundamentally it boils down to what biological questions are being investigated. Being explicit about scale in the development of the questions (e.g. conceptual models) may help determine what might actually be reasonable to try to answer as well as what tools might be useful (e.g. remotelysensed data or not). There is a need for both approaches - the coarse, top-down approach that provides a context or framework and understanding of the detailed, fine-scale data obtained from instrumented birds. We can undertake research using either approach, but integration of the 2 is the key to further developing a full appreciation of the interaction of seabirds and the marine environment.

As it is, atlas-type seabird data (Eulerian) are being applied in the identification of major seabird 'hotspots.' This information will be invaluable for identifying and supporting stretches of the ocean that should be designated as MPAs (Harris et al. 2007) or managing human activities in other ways (e.g. NOAA 2008). Such data are especially valuable when combined with Lagrangian data to identify true foraging areas, separating foraging from commuting individuals (e.g. Ballard et al. 2011).

Unfortunately, the use of remotely-sensed ocean variables is also once again diverting our efforts away from placing seabirds in the ocean as important members of multispecies communities and important players in food-web structuring. While the Lagrangian approach has been invaluable in addressing problems related to single, often special-status species (the source of funding) or special scenarios (e.g. bycatch), it is getting away from an ecosystem perspective, which is needed for application of ecosystembased management of marine resources. Whether the pieces can be put together some day remains to be seen (see below). Only a few studies, such as those by Grémillet et al. (2008), Takahashi et al. (2008), or Pichegru et al. (2010), have matched satellite tracking with the assessment of prey distribution, but even in those cases, too, we are dealing with single seabird species devoid of any interactions with other predators, competitors, or facilitators in the ocean.

Remaining for the future are efforts that combine Eulerian and Lagrangian strategies, thus, to reveal the 3-dimensional (3D) spatial use by predatory fish, seabirds and marine mammals, as interacting species, within a well quantified 3D prey field. In other words, a GLOBEC-type study in which the main bird, mammal, and fish predators are being tracked within a well quantified and varying distribution of prey, i.e. the ultimate study of marine predator-prey patch use. In that way the competition and facilitation that is part of these predators' exploitation strategies can be revealed (see Ainley et al. 2005, 2009). On the other hand, time may be drawing short to undertake such projects as ship costs rise, and oceanographers, themselves enamored by the electronic revolution, resort more and more to autosubs and sea gliders to understand physical and biotic variability in the ocean. On such ocean-going vehicles, which can stay deployed for months and thus are ideal for oceanographers' purposes, no room exists for seabird sighting.

Acknowledgements. We thank G. Hunt and R. Wilson for inviting us to participate in their World Seabird Conference symposium, of which this paper was a part; L. Ballance for discussions towards formulating this paper; Y. Tremblay for advice and sharing of his publication data base; and S. Bartle for helping to identify several difficult-to-find early publications. S. Howell, G. Hunt, P. Pyle, M. Tasker, and an anonymous reviewer provided helpful comments to improve the manuscript. D.G.A.'s effort was funded by National Science Foundation grant OPP 0440463. Any use of trade, product, or firm names is for descriptive purposes only and does not imply endorsement by the US Government.

\section{LITERATURE CITED}

Abrams RW (1985) Environmental determinants of pelagic seabird distribution in the African sector of the southern ocean. J Biogeogr 12:473-492

Abrams RW, Griffiths AM (1981) Ecological structure of the pelagic seabird community in the Benguela Current region. Mar Ecol Prog Ser 5:269-277

Abrams RW, Lutjeharms JRE (1986) Relationship between seabirds and meso-scale hydrographic features in the Agulhas Current retroflection region. In: Quellet H (ed) Acta XIX Congr Int Ornithol, Vol I. National Museum of Natural Sciences, Ottawa, p 991-996

Abrams RW, Underhill LG (1986) Relationships of pelagic 
seabirds with the Southern Ocean environment assessed by correspondence analysis. Auk 103:221-225

Ainley DG, Hyrenbach KD (2010) Top-down and bottom-up factors affecting seabird population trends in the California current system (1985-2006). Prog Oceanogr 84: $242-254$

Ainley DG, O'Connor EF, Boekelheide RJ (1984) Ecology of seabirds in the Ross Sea, Antarctica. Monograph 32. American Ornithologists' Union, Washington, DC

Ainley DG, Smith WO, Sullivan CW, Torres JJ, Hopkins TL (1986) Antarctic mesopelagic micronekton: evidence from seabirds that pack ice affects community structure. Science 232:847-849

Ainley DG, Ribic CA, Fraser WR (1992) Does prey preference affect habitat choice in Antarctic seabirds? Mar Ecol Prog Ser 90:207-221

Ainley DG, Jacobs S, Ribic C, Gaffney I (1998) Seabirds and oceanic features of the Amundsen and southern Bellingshausen Seas, late summer-early autumn 1994. Antarct Sci 10:111-123

Ainley DG, Spear LB, Tynan CT, Barth JA, Cowles TJ, Pierce SD (2005) Factors affecting occurrence patterns of seabirds in the northern California Current, spring and summer 2000. Deep-Sea Res II Top Stud Oceanogr 52: 123-143

Ainley DG, Dugger KD, Ford RG, Pierce SD and others (2009) The spatial association of predators and prey at frontal features in the northern California Current: competition, facilitation, or merely co-occurrence? Mar Ecol Prog Ser 389:271-294

Alexander WB (1955) Birds of the ocean. GW Putman's Sons, New York, NY

Ashmole NP (1971) Seabird ecology and the marine environment. In: Farner DS, King JR (eds) Avian biology, Vol 1. Academic Press, New York, NY, p 223-286

Bailey SF, Pyle P, Spear L (1989) Dark Pterodroma petrels in the North Pacific: identification, status, and Pacific North American occurrence. Am Birds 43:400-450

Ballance LT, Pitman RL, Reilly SB (1997) Seabird community structure along a productivity gradient: importance of competition and energetic constraint. Ecology 78: 1502-1518

Ballance LT, Ainley DG, Hunt GL Jr (2001) Seabird foraging ecology. In: Steele J, Thorpe S, Tarekian K (eds) Encyclopedia of ocean sciences. Academic Press, London, p 2636-2644

Ballance LT, Pitman RL, Fiedler PC (2006) Oceanographic influences on seabirds and cetaceans of the eastern tropical Pacific: a review. Prog Oceanogr 69:360-390

Ballard G, Jongsomjit D, Veloz SD, Ainley DG (2011) Coexistence of mesopredators in an intact polar ocean ecosystem: the basis for defining a Ross Sea Marine Protected Area. Biol Conserv doi:10.1016/j.biocon.2011.11.017

Batchelder HP, Lessard EJ, Strub PT, Weingartner TJ (eds) (2005) U.S. GLOBEC biological and physical studies of plankton, fish and higher trophic level production, distribution and variability in the northeast Pacific. Deep-Sea Res II Top Stud Oceanogr 52:1-374

Beck RH (1910) Water birds in the vicinity of Point Pinos, California. Proc Calif Acad Sci 3:57-72

Bourne WRP, Warham J (1966) Geographical variation in the giant petrels of the genus Macronectes. Ardea 54:45-67

Bretagnolle V, Thomas TE (1990) Seabird distribution between Tasmania and Adélie Land (Antarctica), and comparison with nearby Antarctic sectors. Emu 90:97-107
Briggs KT, Breck Tyler WM, Lewis DB, Carlson DR (1987) Bird communities at sea off California: 1975 to 1983. Stud Avian Biol 11:1-74

Brinkley ES, Howell SNG, Force MP, Spear LB, Ainley DG (2000) Status of the Westland petrel (Procellaria westlandica) off South America. Notornis 47:179-183

Brown RGB (1980) Seabirds as marine animals. In: Burger J, Olla BL, Winn HE (eds) Behavior of marine animals. Plenum Press, New York, NY, p 1-39

> Brown RGB, Cooke F, Kinnear PK, Mills EL (1975) Summer seabird distributions in the Drake Passage, Chilean fjords and off southern South America. Ibis 117:339-356

Brown RGB, Nettleship DN, Germain P, Tull CE, Davis T (1975, 1977, 1986) Atlas of eastern Canadian seabirds. Canadian Wildlife Service, Ottawa

Burnham KP, Anderson DR, Laake JL (1980) Estimation of density from line transect sampling of biological populations. Wildl Monogr 72:1-202

Chapman EW, Ribic CA, Fraser WR (2004) The distribution of seabirds and pinnipeds in Marguerite Bay and their relationship to physical features during austral winter 2001. Deep-Sea Res II Top Stud Oceanogr 51:2261-2278

Clarke ED, Spear LB, McCracken ML, Marques FFC, Borchers DL, Buckland ST, Ainley DG (2003) Validating the use of generalized additive models and at-sea surveys to estimate size and temporal trends of seabird populations. J Appl Ecol 40:278-292

Fauchald P, Erikstad KE, Skarsfjord H (2000) Scaledependent predator-prey interactions: the hierarchical spatial distribution of seabirds and prey. Ecology 81: 773-783

Ford RG, Ainley DG, Casey JL, Keiper CA, Spear LB, Ballance LT (2004) The biogeographic patterns of seabirds in the central portion of the California Current. Mar Ornithol 32:77-96

Fraser WR, Ainley DG (1986) Ice edges and seabird occurrence in Antarctica. BioScience 36:258-263

Gaston AB, Smith GEJ (1984) The interpretation of aerial surveys for seabirds: some effects of behaviour. Occas Pap No. 53. Canadian Wildlife Service. Environment Canada, Ottawa

Gill FB (1967) On the pelagic distribution of seabirds in the western Indian Ocean. Proc US Natl Mus 123:1-33

Gould PJ, Forsell DJ (1989) Techniques for shipboard surveys of marine birds. Fish and Wildlife Tech Rep 25. US Department of the Interior, Fish and Wildlife Service, Washington, DC

Gould PJ, Forsell DJ, Lensink CJ (1982) Pelagic distribution and abundance of seabirds in the Gulf of Alaska and eastern Bering Sea. FWS/OBS-82/48. US Department of the Interior, Fish and Wildlife Service, Washington, DC

Grémillet D, Pichegru L, Kuntz G, Woakes AG, Wilkinson S, Crawford RJM, Ryan PG (2008) A junk-food hypothesis for gannets feeding on fishery waste. Proc Biol Sci 275: 1149-1156

Haney JC (1986a) Seabird segregation at Gulf Stream frontal eddies. PSZNI Mar Ecol 28:279-285

> Haney JC (1986b) Seabird affinities for Gulf Stream frontal eddies: responses of mobile marine consumers to episodic upwelling. J Mar Res 44:361-384

Haney JC (1986c) Seabird patchiness in tropical oceanic waters: the influence of Sargassum 'reefs'. Auk 103: $141-151$

Haney JC (1987) Effects of a Gulf Stream warm-core ring on summer seabird distribution in the northwest Atlantic 
Ocean. Limnol Oceanogr 32:665-673

Harper PC, Kinsky FC (1978), Southern albatrosses and petrels: an identification guide. Biology Society, Victoria University, Wellington

> Harris J, Haward M, Jabour J, Woehler EJ (2007) A new approach to selecting Marine Protected Areas (MPAs) in the Southern Ocean. Antarct Sci 19:189-194

Harrison P (1983) Seabirds: an identification guide. Houghton Mifflin, Boston, MA

Haury LR, McGowen JA, Wiebe PH (1978) Patterns and processes in the time-space scales of plankton distributions. In: Steele JH (ed) Spatial pattern in plankton communities. Plenum Press, New York, NY, p 277-327

Hofmann EE, Wiebe PH, Costa DP, Torres JJ (eds) (2004) Integrated ecosystem studies of western Antarctic Peninsula continental shelf waters and related Southern Ocean regions. Deep-Sea Res II Top Stud Oceanogr 51: 1921-2344

Howell SNG (2009) Identification of immature Salvin's, Chatham and Buller's albatrosses. Neotrop Birding 4: 19-25

Howell SNG (2012) Petrels, albatrosses and storm-petrels of North America: a photographic guide. Princeton University Press, Princeton, NJ

Howell SNG, McGrath T, Hunefeld WT, Feenstra JS (2010) Occurrence and identification of the Leach's stormpetrel (Oceanodroma leucorhoa) complex off southern California. North Am Birds 63:540-549

Huettmann F, Diamond AW (2006) Large-scale effects on the spatial distribution of seabirds in the Northwest Atlantic. Landsc Ecol 21:1089-1108

Hunt GL Jr, Harrison NH (1990) Foraging habitat and prey taken by least auklets at King Island, Alaska. Mar Ecol Prog Ser 65:141-150

Hunt GL Jr, Schneider D (1981) Seabird distribution and food consumption. PROBES Progress Report 1980. PROBES, Institute of Marine Sciences, University of Alaska, Fairbanks, AK

Hunt GL Jr, Schneider D (1987) Scale dependent processes in the physical and biological environment of marine birds. In: Croxall J (ed) Seabirds: feeding biology and role in marine ecosystems. Cambridge University Press, Cambridge, p 7-41

Hunt GL Jr, Stabeno PJ (2005) Oceanography and ecology of the Aleutian Archipelago: spatial and temporal variation. Fish Oceanogr 14(Suppl 1):292-306

Hunt GL Jr, Harrison NM, Cooney T (1990) Foraging of least auklets: the influence of hydrographic structure and prey abundance. Stud Avian Biol 14:7-22

> Hunt GL Jr, Heinemann D, Everson I (1992) Distributions and predator-prey interactions of macaroni penguins, Antarctic fur seals and Antarctic krill near Bird Island, South Georgia. Mar Ecol Prog Ser 86:15-30

Hunt GL Jr, Russell RW, Coyle KO, Weingartner T (1998) Comparative foraging ecology of planktivorous auklets in relation to ocean physics and prey availability. Mar Ecol Prog Ser 167:241-259

Jahncke J, Coyle KO, Hunt GL Jr (2005) Seabird distribution, abundance and diets in the central and eastern Aleutian Islands. Fish Oceanogr 14(Suppl 1):160-177

> Jespersen P (1924) The frequency of birds over the high Atlantic Ocean. Nature 114:281-283

Jespersen P (1929) On the frequency of birds over the high Atlantic Ocean. Verhandl VI Internat Ornith Kongress, Copenhagen, p 163-172
Kinder TH, Hunt GL Jr, Schneider D, Schumacher JD (1983) Correlation between seabirds and oceanic fronts around the Pribilof Islands, Alaska. Estuar Coast Shelf Sci 16:309-319

King WB (1967) Seabirds of the tropical Pacific Ocean. Smithsonian Institution, Washington, DC

King WB (1970) The trade wind zone oceanography pilot study, Part 7: observations of seabirds. Spec Sci Rep Fisheries 586. US Department of the Interior, Fish and Wildlife Service, Washington, DC

King WB (ed) (1974) Pelagic studies of seabirds in the central and eastern Pacific Ocean. Smithsonian Institution, Washington, DC

> Ladd C, Jahncke J, Hunt GL Jr, Coyle KO, Stabeno PJ (2005) Hydrographic features and seabird foraging in the Aleutian Passes. Fish Oceanogr 14(Suppl 1):178-195

Logerwell EA, Hewitt RP, Demer DA (1998) Scaledependent spatial variance patterns and correlations of seabirds and prey in the southeastern Bering Sea as revealed by spectral analysis. Ecography 21:212-223

> Lombard AT, Reyers B, Schonegevel LY, Cooper J and others (2007) Conserving pattern and process in the Southern Ocean: designing a Marine Protected Area for the Prince Edward Islands. Antarct Sci 19:39-54

Manikowski S (1971) The influence of meteorological factors on the behaviour of sea birds. Acta Zool Cracov 16:581-667

Manikowski S (1975) The effect of weather on the distribution of kittiwakes and fulmars in the North Atlantic. Acta Zool Cracov 20:489-497

Mason JW, McChesney GJ, McIver WR, Carter HR and others (2007) At-sea distribution and abundance of seabirds off Southern California: a 20-year comparison. Stud Avian Biol 33:1-101

Mehlum F, Hunt GL Jr, Klusek Z, Decker MB, Nordlund N (1999) Scale-dependent correlations between the abundance of Brunnich's guillemots and their prey. J Anim Ecol 68:60-73

Murphy RC (1936) The oceanic birds of South America. Macmillan, New York, NY

Murphy RC (1965) Logbook for Grace. Time Books Inc, New York, NY

Nicol S, Pauly T, Bindoff NL, Wright S and others (2000) Ocean circulation off east Antarctica affects ecosystem structure and ice extent. Nature 406:504-507

NOAA (National Oceanic and Atmospheric Administration) (2008) Cordell Bank, Gulf of the Farallones, and Monterey Bay National Marine Sanctuaries, Final Environmental Impact Statement. NOAA, Washington, DC

Nur N, Jahncke J, Herzog MP, Howar J and others (2011) Where the wild things are: predicting hotspots of seabird aggregations in the California Current System. J Appl Ecol 21:2241-2257

> O'Driscoll RL (1998) Description of spatial pattern in seabird distributions along line transects using neighbour $K$ statistics. Mar Ecol Prog Ser 165:81-94

Obst BS (1985) Densities of Antarctic seabirds at sea and the presence of krill Euphausia superba. Auk 102:540-549

Piatt JF (1990) Aggregative response of common murres and Atlantic puffins to their prey. Stud Avian Biol 14:36-51

> Pichegru L, Grémillet D, Crawford RJM, Ryan PG (2010) Marine no-take zone rapidly benefits endangered penguin. Biol Lett 6:498-501

Pocklington R (1965) A summary of birds seen over the western Indian Ocean, August-November 1963. Ibis 107: 385-386 
Pocklington R (1979) An oceanographic interpretation of seabird distributions in the Indian Ocean. Mar Biol 51: 9-21

Pyle P, Spear LB, Ainley DG (1993) Observations of darkrumped petrels off Oregon and California. West Birds 24:110-112

Ralph CJ, Hunt GL Jr, Raphael MG, Piatt JF (eds) (1995) Ecology and conservation of the marbled murrelet. Gen Tech Rep, PSW-GTR-152. Pacific Southwest Research Station, Forest Service, US Dept Agriculture, Albany, CA

Rau GH, Ainley DG, Bengtson JL, Torres JJ, Hopkins TL (1992) ${ }^{15} \mathrm{~N} /{ }^{14} \mathrm{~N}$ and ${ }^{13} \mathrm{C} /{ }^{12} \mathrm{C}$ in Weddell Sea birds, seals, and fish: implications for diet and trophic structure. Mar Ecol Prog Ser 84:1-8

Raymond B, Woehler EJ (2003) Predicting seabirds at sea in the Southern Indian Ocean. Mar Ecol Prog Ser 263: 275-285

Raymond B, Shaffer SA, Sokolov S, Woehler EJ and others (2010) Shearwater foraging in the Southern Ocean: the roles of prey availability and winds. PLoS ONE 5:e10960

Ribic CA, Ainley DG (1988/89) Constancy of seabird species assemblages: an exploratory look. Biol Oceanogr 6: 175-202

Ribic CA, Ainley DG (1997) The relationships of seabird assemblages to physical habitat features in Pacific equatorial waters during spring 1984-1991. ICES J Mar Sci 54:593-599

- Ribic CA, Ainley DG, Spear LB (1997) Scale-related seabird-environmental relationships in Pacific equatorial waters, with reference to El Niño-Southern Oscillation events. Mar Ecol Prog Ser 156:183-203

Ribic CA, Chapman EW, Fraser WR, Lawson GL, Wiebe PH (2008) Top predators in relation to bathymetry, ice, and krill during austral winter in Marguerite Bay, Antarctica. Deep-Sea Res Part II Top Stud Oceanogr 55:485-499

Robb M, Mullarney K, The Sound Approach (2008) Petrels night and day: a Sound Approach guide. The Sound Approach, Dorset

Russell RW, Hunt GL (1992) Foraging in a fractal environment: spatial patterns in a marine predator-prey system. Landsc Ecol 7:195-209

Ryan PG, Cooper J (1989) The distribution and abundance of aerial seabirds in relation to Antarctic krill in the Prydz Bay region, Antarctica, during summer. Polar Biol 10: 199-209

Sala E, Aburto-Oropeza O, Paredes G, Parra I, Barrera JC, Dayton PK (2002) A general model for designing networks of marine reserves. Science 298:1991-1993

Schneider DC, Duffy DC (1985) Scale-dependent variability in seabird abundance. Mar Ecol Prog Ser 25:211-218

Schneider DC, Piatt JF (1986) Scale-dependent correlation of seabirds with schooling fish in a coastal ecosystem. Mar Ecol Prog Ser 32:237-246

Schneider D, Harrison N, Hunt GL (1987) Variation in attendance at fronts by marine birds in the Bering Sea. Estuar Coast Shelf Sci 25:135-141

Shaffer SA, Tremblay Y, Weimerskirch H, Scott D and others (2006) Migratory shearwaters integrate oceanic resources across the Pacific Ocean in an endless summer. Proc Natl Acad Sci USA 103:12799-12802

Shealer DA (2002) Foraging behavior and food of seabirds. In: Schreiber EA, Burger JA (eds) Biology of marine birds. CRC Press, Boca Raton, FL, p 137-177

Southwell C, Low M (2009) Black and white or shades of grey? Detectability of Adélie penguins during shipboard surveys in the Antarctic pack ice. J Appl Ecol 46: 136-143

Spear LB, Ainley DG (1997) Flight speed of seabirds in relation to wind speed and direction. Ibis 139:234-251

Spear LB, Nur N, Ainley DG (1992) Estimating absolute densities of flying seabirds using analyses of relative movement. Auk 109:385-389

Spear LB, Ainley DG, Nur N, Howell SNG (1995) Population size and factors affecting at-sea distribution of four endangered procellariids in the tropical Pacific. Condor 97:613-638

Stabeno PJ, Hunt GL Jr, Macklin SA (2005) Introduction to processes controlling variability in productivity and ecosystem structure of the Aleutian Archipelago. Fish Oceanogr 14(Suppl 1):1-2

- Takahashi A, Matsumoto K, Hunt GL Jr, Shultz MT and others (2008) Thick-billed murres use different diving behaviors in mixed and stratified waters. Deep-Sea Res II Top Stud Oceanogr 55:1837-1845

Tasker ML, Jones PH, Dixon T, Blake BF (1984) Counting seabirds at sea from ships: a review of methods employed and a suggestion for a standardized approach. Auk 101:567-577

- Trebilco R, Gales R, Baker GB, Terauds A, Sumner MD (2008) At sea movement of Macquarie Island giant petrels: relationships with marine protected areas and regional fisheries management organisations. Biol Conserv 141:2942-2958

> Tremblay Y, Bertrand S, Henry RW, Kappes MA, Costa DP, Shaffer SA (2009) Analytical approaches to investigating seabird-environment interactions: a review. Mar Ecol Prog Ser 391:153-163

Tuck GA (1980) A guide to seabirds on the ocean routes. Collins, New York, NY

Updegraff GE, Hunt GL Jr (1985) Field use of microcomputers for the collection of seabird data. Pac Seabird Group Bull 12:19

Van Franeker JA (1994) A comparison of methods for counting seabirds at sea in the southern Ocean. J Field Ornithol 65:96-108

Veit RR, Silverman ED, Everson I (1993) Aggregation patterns of pelagic predators and their principal prey, Antarctic krill, near South Georgia. J Anim Ecol 62:551-564

> Vlietstra LS, Coyle KO, Kachel NB, Hunt GL Jr (2005) Tidal front affects the size of prey used by a top marine predator. Fish Oceanogr 14(Suppl 1):196-211

Watson GE (1965) Preliminary Smithsonian identification manual: seabirds of the tropical Atlantic. Smithsonian Institution, Washington, DC

Watson GE, Zusi RL, Storer RE (1963) Preliminary field guide to the birds of the Indian Ocean. Smithsonian Institution, Washington, DC

Woehler EJ, Cooper J, Croxall JP, Fraser WR and others (2001) A statistical assessment of the status and trends of Antarctic and subantarctic seabirds. Report on SCAR BBS Workshop on Southern Ocean seabird populations. SCAR, Cambridge

Woodby D (1984) The April distribution of murres and prey patches in the southeastern Bering Sea. Limnol Oceanogr 29:181-188

Wynne-Edwards VC (1935) On the habits and distribution of birds on the North Atlantic. Proc Boston Soc Nat Hist 40: 233-346 
Appendix 1. Compilation of at-sea seabird atlases that provide information on distribution, including 'hotspots' of high seabird concentration; many have associated data bases. Very few of these are included in the Literature Cited

Ainley DG, O'Connor EF, Boekelheide RJ (1984) Ecology of seabirds in the Ross Sea, Antarctica. Monogr No 32. American Orinithologists' Union, Washington, DC

Allen SG (1994) The distribution and abundance of marine birds and mammals in the Gulf of the Farallones and adjacent waters, 1985-1992. PhD dissertation, University of California, Berkeley, CA

Audubon Alaska (2010) Arctic marine synthesis: atlas of the Chukchi and Beaufort Seas. Available at http://ak. audubon.org/birds-science-education/arctic-marinesynthesis-atlas-chukchi-and-beaufort-seas

Bierman WH, Voous KH (1950) Birds observed and collected during the whaling expeditions of the Willem Barendsz in the Antarctic, 1946-1947 and 1947-1948. Ardea 37:1-123

Birdlife South Africa (2009-2011) AS@S: atlas of seabirds at sea. Available at http://seabirds.adu.org.za/

Briggs KT, Tyler WB, Lewis D, Carlson D (1987) Bird communities at sea off California: 1975-1983. Stud Avian Biol 11. Cooper Ornithological Society, Berkeley, CA (Note: these data are now available in the Compilation of Data At-Sea [CDAS] data set; see main text)

Brown RGB $(1977,1986)$ Revised atlas of eastern Canadian seabirds. Supplement 1 Halifax-Bermuda transects. Canadian Wildlife Service, Ottawa

Brown RGB, Nettleship DN, Germain P, Tull CE, Davis T (1975) Atlas of eastern Canadian seabirds. Canadian Wildlife Service, Ottawa

Carter IC, Williams JM, Webb A (1993) Seabird concentrations in the North Sea: an atlas of vulnerability to surface pollutants. Joint Nature Conservation Committee, Peterborough

Camphuysen CJ, Leopold MF (1994) Atlas of seabirds in the southern North Sea. Institute for Forestry and Nature Research, Dutch Seabird Group and Netherlands Institute for Sea Research, The Netherlands, Texel

Clapp RB, Banks RC, Morgan-Jacobs D, Hoffman WA (1982) Marine birds of the southeastern United States and Gulf of Mexico Part I: Gaviiformes through Pelecaniformes. FWS/OBS-82/01. US Department of the Interior, Fish and Wildlife Service, Office of Biological Services, Washington, DC

Clapp RB, Morgan-Jacobs D, Banks RC (1983) Marine birds of the southeastern United States and Gulf of Mexico Part III: Charadriiformes. FWS/OBS-83/30. US Department of the Interior, Fish and Wildlife Service, Office of Biological Services, Washington, DC

Fritts TH, Irvine AB, Jennings RD, Collum LA, Hoffman W, McGehee MA (1983) Turtles, birds and mammals in the northern Gulf of Mexico and nearby Atlantic waters. US Department of Commerce National Technical Information Service, Springfield, VA

Gould PJ, Forsell DJ, Lensink CJ (1982) Pelagic distribution and abundance of seabirds in the Gulf of Alaska and eastern Bering Sea. USFWS Biol Serv Prog FWS/OBS82/48. US Department of the Interior, Fish and Wildlife Service, Washington, DC

Hess NA, Ribic CA (2000) Seabird ecology. In: Davis R, Evans W, Wursig B (eds) Distribution and abundance of cetaceans in the northern Gulf of Mexico, Vol II. Tech Rep OCS Study MMS 2000-003. US Department of the Interior, Minerals Management Service, New Orleans, LA, p 275-315
Hunt GL Jr, Gould PJ, Forsell DJ, Peterson H Jr (1981) Pelagic distribution of marine birds in the eastern Bering Sea. In: Hood DW, Calder JA (eds) The eastern Bering Sea shelf: oceanography and resources, Vol 2. US Department of Commerce National Oceanic and Atmospheric Administration Office of Marine Pollution Assessment, Washington, DC, p 689-718

Kenyon JK, Morgan KH, Bentley MD, McFarlane Tranquilla LA, Moore KE (2009) Atlas of pelagic seabirds off the west coast of Canada and adjacent areas. Tech Rep Ser No 499. Canadian Wildlife Service, Pacific Yukon Region, Delta

Lock AR, Brown RGB, Gerriets SH (1994) Gazetteer of marine birds in Atlantic Canada. Canadian Wildlife Service, Ottawa

Mason J, McChesney GJ, McIver WR, Carter HR and others (2007) At-sea distribution and abundance of seabirds off Southern California: a 20-year comparison. Stud Avian Biol 33. Cooper Ornithological Society, Berkeley, CA (Note: these data are now available in the CDAS data set; see main text)

Morgan KH, Vermeer K, McKelvey RW (1991) Atlas of pelagic birds of western Canada. Occas Pap 72. Canadian Wildlife Service, Ottawa

NOAA (National Oceanic and Atmospheric Administration) (1987) Bering, Chukchi, and Beaufort Seas coastal and ocean zones strategic assessment. Data Atlas. NOAA, Washington, DC

NOAA (2008) Cordell Bank, Gulf of the Farallones, and Monterey Bay national marine sanctuaries. Final environmental impact statement. NOAA, Washington, DC. Available at http://montereybay.noaa.gov/research/ techreports/trnccos2007.html

Peake DE (1996) Bird surveys. In: Davis RW, Fargion GS (eds) Distribution and abundance of cetaceans in the north-central and western Gulf of Mexico, final report, Vol. II: Tech Rep OCS Study MMS 96-0027. US Department of the Interior, Minerals Management Service, Gulf of Mexico OCS Region, New Orleans, LA, p 271-304

Piatt JF, Drew GS, Irons DB (2006) Atlas of seabird distribution at sea in Alaska. USGS Alaska Science Center, Anchorage, AK. Available at www.absc.usgs.gov/research/ NPPSD/

Pitman RL (1986) Atlas of seabird distribution and relative abundance in the eastern tropical Pacific. Admin Rep No. LJ-86-02C. NOAA, Southwest Fisheries Science Center, La Jolla, CA

Reid TA, Hindell MA, Eades DW, Newman M (2002) Seabird atlas of south-eastern Australian waters. Birds of Australia Monogr 4. Available at www.birdsaustralia. com.au/reports-newsletters/ba-monographs.html

SCAR/SCOR/IABO/ACMRR (Group of Specialists on Southern Ocean Ecosystems and their Living Resources) (1981) Post-FIBEX data workshop: seabird ecology. Biomass Rep Ser No. 22. SCAR, Cambridge

SCAR/SCOR/IABO/ACMRR (Group of Specialists on Southern Ocean Ecosystems and their Living Resources) (1985) FIBEX seabird data interpretation workshop. Biomass Rep Ser No. 44. SCAR, Cambridge

Shuntov VP (1972) Seabirds and the biological structure of the ocean. TT-74-55032. National Technical Information 
Service, US Department of Commerce, Washington, DC [translated from Russian]

Skov H, Durink J, Leopold MF, Tasker ML (1995) Important bird areas for seabirds in the North Sea. BirdLife International, Cambridge

Stone CJ, Webb A, Barton C, Ratcliffe N and others (1995) An atlas of seabird distribution in north-west European waters. Joint Nature Conservation Committee, Peterborough. Available at http://jncc.defra.gov.uk/default. aspx? page $=2407$

Tasker ML (1987) Seabirds in the North Sea. Joint Nature Conservation Committee, Peterborough

Tasker ML, Webb A, Hall AJ, Pienkowski MW, Langslow DR (1987) Vulnerable concentrations of marine birds west of Britain. Joint Nature Conservation Committee, Peterborough

Tasker ML, Pienkowski MW (1990) Vulnerable concentrations of birds in the North Sea. Joint Nature Conservation Committee, Peterborough

Submitted: August 31, 2011; Accepted: November 23, 2011
Watson GE (1971) Birds of the Antarctic and subantarctic. Map Folio Ser No. 14. American Geographical Society, New York, NY

Webb A (1990) Seabird distribution west of Britain. Joint Nature Conservation Committee, Peterborough

Webb A, Stronach A, Seabirds at Sea Team (1995) Vulnerable concentrations of seabirds south and west of Britain. Joint Nature Conservation Committee, Peterborough

Webb A, Stronach A, Seabirds at Sea Team (1995) Vulnerable concentrations of seabirds south and west of Britain. Joint Nature Conservation Committee, Petersborough

White RW, Gillon KW, Black AD, Ried JB (2002) The distribution of seabirds and marine mammals in Falkland Islands waters. Joint Nature Conservation Committee, Peterborough

Woehler EJ, Hodges CL, Watts DJ (1990) An atlas of the pelagic distribution and abundance of seabirds in the southern Indian Ocean, 1981-1990. ANARE Res Notes, No. 77, Kingston

Proofs received from author(s): March 21, 2012 